\title{
Design and Simulation of a Servo-Drive Motor Using ANSYS Electromagnetics
}

\author{
Vladyslav Pliuhin (D), Oleksandr Aksonov (D), Yevgen Tsegelnyk (D), Sergiy Plankovskyy (D), \\ Volodymyr Kombarov (D), and Lidiia Piddubna (D)
}

O. M. Beketov National University of Urban Economy in Kharkiv, Kharkiv, Ukraine

\author{
Article History \\ Received: \\ 07 November 2021 \\ Accepted: \\ 27 December 2021 \\ Published online: \\ 30 December 2021

\section{Keywords} \\ Servo-drive Motor; \\ Incorporated Magnets; \\ ANSYS Simplorer; \\ Twin Builder; \\ Motor Parameters
}

\begin{abstract}
The paper is devoted to determining the output parameters of a servomotor, which belongs to synchronous machines with permanent magnets, in order to further determine the characteristics of transient modes in the software package ANSYS Electromagnetics. RMxprt, part of ANSYS Electromagnetics, allows to determine the parameters of windings, losses, motor performance, but requires filling out a form with a complete set of geometric dimensions and winding data. Of course, such data are not available in the motor data sheet, so the first task solved in the paper is to determine all the necessary and sufficient parameters to perform the calculation in RMxprt. The results of the calculations were compared with the measurements on the experimental servomotor EMG-10APA22. This paper shows how to export a servomotor object from RMxprt to the Simplorer workspace, which is also part of the ANSYS Electromagnetics. According to the simulation results in ANSYS Simplorer, the characteristics of the transient modes of the servomotor powered by a stable three-phase source are obtained. Prospects for further research related to the improvement of the simulation model in ANSYS Simplorer are presented.
\end{abstract}

\section{INTRODUCTION}

A servomotor is a motor that allows to control the precise position of the motor shaft as well as the speed and/or acceleration. For this, appropriate sensors and automatic control methods are used. Servomotors used to be auxiliary drives that were designed for machine tool applications [1-3].

Servomotors can be divided into synchronous and asynchronous [4]. But it is always a drive operating under conditions of electronic control of position, speed or torque - or a combination of these parameters. This places very high demands on dynamics, control ranges and/or movement accuracy. Servomotors are usually used in combination with automation and control systems, for example in packaging machines [5].

Synchronous servomotors are drives in which the rotor is synchronously driven by a rotating field in the stator using permanent magnets attached to it. The synchronous motor rotates synchronously with the applied frequency of the rotating field. This version of the drive is powered by a frequency con- verter that provides a suitable, controlled threephase current. The servomotors can be adapted to high dynamics or high loads, depending on the application. Typical applications are food processing, construction, automotive, packaging and woodworking [4]. In this regard, the analysis of the parameters and characteristics of the servo motor for subsequent optimization in specific areas of use seems relevant [6-8].

The aim of this paper is to analyze the characteristics of the servo motor used by the authors in the mechanism for moving the axes of a gantry $\mathrm{CNC}$ machine in the drive of longitudinal displacements. The obtained data will allow to optimize the machine control system, having previously tested it on a simulation model. In turn, this will avoid costs both when performing tests and selecting associated mechanical components, as well as when setting up a control system.

The portal-type machine, on the basis of which the experimental complex is created, in the factory configuration of the supplier is equipped with a railgear transmission on the axes of longitudinal movement $X, Y$ (Fig. 1).

Corresponding author: oleksandr.aksonov@kname.edu.ua (Oleksandr Aksonov)

(c) 2021 The Author(s). Published by O. M. Beketov National University of Urban Economy in Kharkiv Use permitted under Creative Commons Attribution 4.0 International (CC BY 4.0)

Cite as: Pliuhin, V., Aksonov, O., Tsegelnyk, Y., Plankovskyy, S., Kombarov, V., \& Piddubna, L. (2021). Design and simulation of a servo-drive motor using ANSYS Electromagnetics. Lighting Engineering \& Power Engineering, 60(3), 112-123. https://doi.org/10.33042/2079-424X.2021.60.3.04 


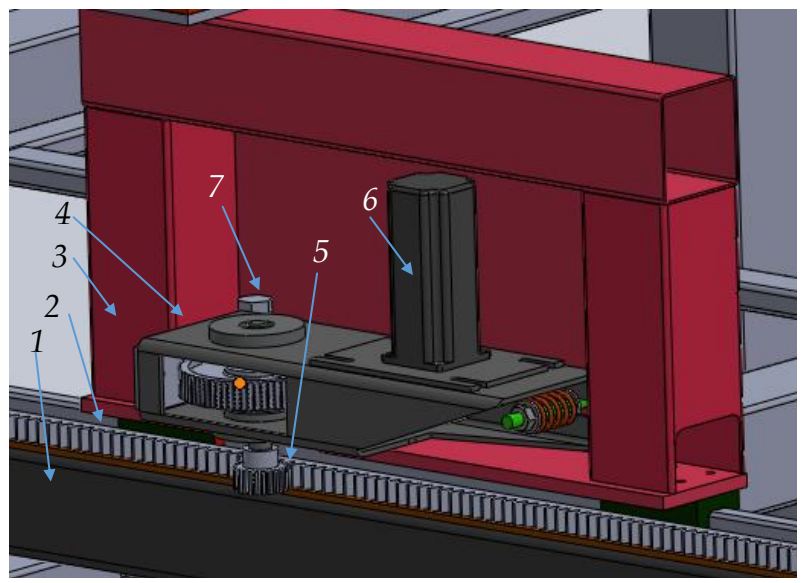

Figure 1. The main elements of the longitudinal drive to move the axis of the portal-type machine

The rack-and-gear 2 is fixed on the frame 1, and the drive gear 5 is driven by a servo motor 6 through a gear-belt gearbox 4 . The gearbox is mounted on the movable support of the portal-type 3 by means of a rotary axis 7 and the gap in the installed gearbox provides reduction of turns with a gear ratio $R=72 / 22=3.27$.

Servomotor EMG-10APA22, which is the aim of calculations, is shown in Fig. 2 [9].

The AC EMG-10 servomotor [9] comes standard with a 2500 pulses per revolution. Incremental encoder, runs at a maximum speed of 3000 RPM, provides peak values up to $300 \%$ of the rated torque and current values, and has a rated torque of $4.78 \mathrm{Nm}$ with a $1.0 \mathrm{~kW}$ power rating. These enclosed and self-cooled motors also provide longer motor life and higher reliability. The EMG-10 AC servomotors enable industrial motion control applications with medium inertia to attain a great combination of speed and positioning functionality.

The passport (rated) data of the servomotor are given in Table 1. Outline drawings of the machine are shown on Fig. 2 (legend corresponds to the dimensions in millimeters given in Table 2).

Fig. 4 shows the rated characteristics of the servomotor operating mode.
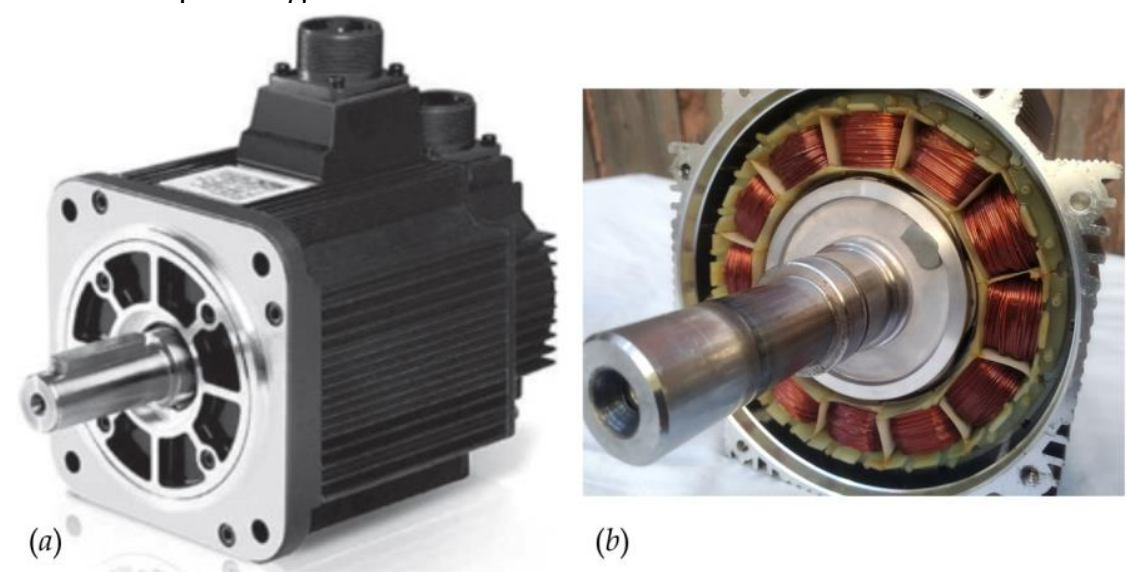

(b)
Table 1. Rated data of the servomotor EMG-10APA22

\begin{tabular}{lcc}
\hline \multicolumn{1}{c}{ Name } & Symbol & Value \\
\hline Rated power, $\mathrm{kW}$ & $P_{n}$ & 1000 \\
Line voltage, $\mathrm{V}$ & $U_{n}$ & 220 \\
Phase current, A & $I_{f}$ & 6 \\
Rated speed, rpm & $n$ & 2000 \\
Frequency, Hz & $f$ & 133 \\
Rated torque, Nm & $M_{n}$ & 4,78 \\
Number of phases & $m$ & 3 \\
Winding connection & - & star \\
Winding resistance, Ohm & $Z$ & 0,8 \\
Electric Time Constant, $\mathrm{ms}$ & $T_{s}$ & 11.57 \\
Inertia, N/s & $J$ & 0.004014 \\
\hline
\end{tabular}

The main parameters, geometric dimensions and winding data of the experimental servomotor are given in Table 3.

\section{PRELIMINARY CALCULATION OF MAIN DIMENSIONS}

The data obtained as a result of disassembling the servomotor, as well as the information available on the dimensional drawings, is not enough for the verification calculation in ANSYS, where a complete set of geometric and winding data is required [1018]. Therefore, preliminary design of the machine must be completed, including the determination of power factor and efficiency targets.

According to the principle of operation, the servomotor belongs to permanent magnet synchronous motors, therefore, the design methodology of such machines will be applied to its calculation [11, 14-16, 19]. The calculation is not performed completely, but only until the point, when the parameters necessary for starting the design in ANSYS are obtained [19]. Thus, it is possible to end with the determination of the basic geometric dimensions and winding data and not perform the calculation of the magnetic circuit, active and inductive resistances of the windings, operating and starting characteristics [2027]:

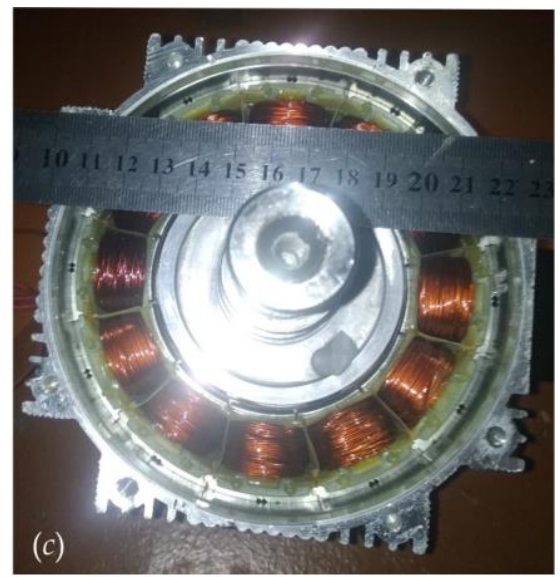

Figure 2. Views of the investigated servomotor: $(a)$ - appearance of the EMG-10APA22 servomotor; $(b)$ - servomotor with the endshield removed (experimental photo); $(c)$ - view of the servomotor coils (photo of the experimental sample) 

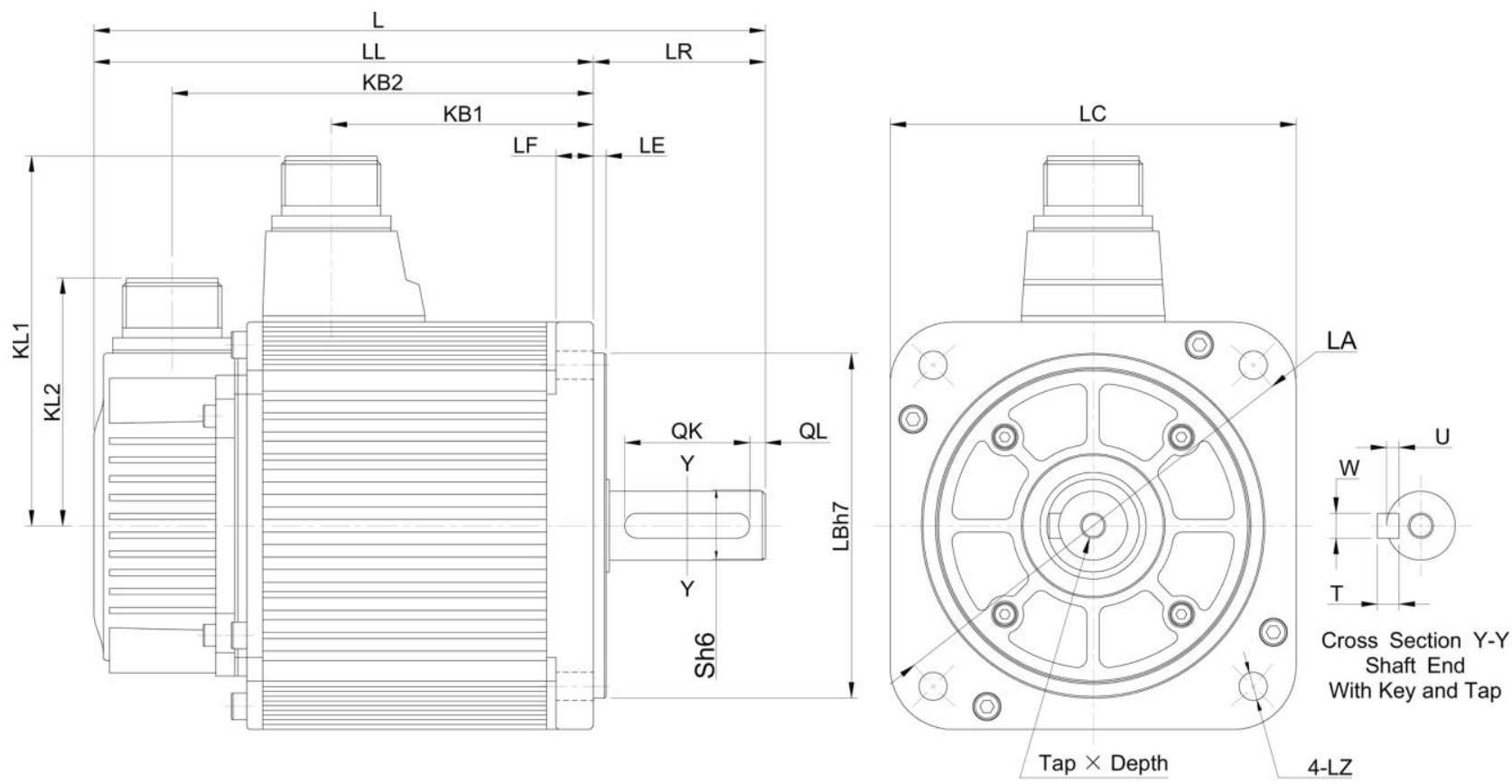

Figure 3. Servomotor EMG-10APA22 outline drawings

Table 2. Servomotor EMG-10APA22 dimensions

\begin{tabular}{|c|c|c|c|c|c|c|c|c|c|c|c|c|c|c|c|c|c|c|}
\hline \multirow{2}{*}{$\mathrm{L}$} & \multirow{2}{*}{ LL } & \multirow{2}{*}{ KB1 } & \multirow{2}{*}{ KB2 } & \multirow{2}{*}{ KL1 } & \multirow{2}{*}{ KL2 } & \multicolumn{7}{|c|}{ Flange Slide } & & \multicolumn{5}{|c|}{ Key } \\
\hline & & & & & & LR & $\mathrm{LE}$ & LF & LC & LA & LB & LZ & & QK & QL & $\mathrm{W}$ & $\mathrm{T}$ & $\mathrm{U}$ \\
\hline 215 & 160 & 84 & 135 & 118 & 79 & 55 & 4 & 12 & 130 & 145 & 110 & 9 & 22 & 40 & 5 & 8 & 7 & 4 \\
\hline
\end{tabular}

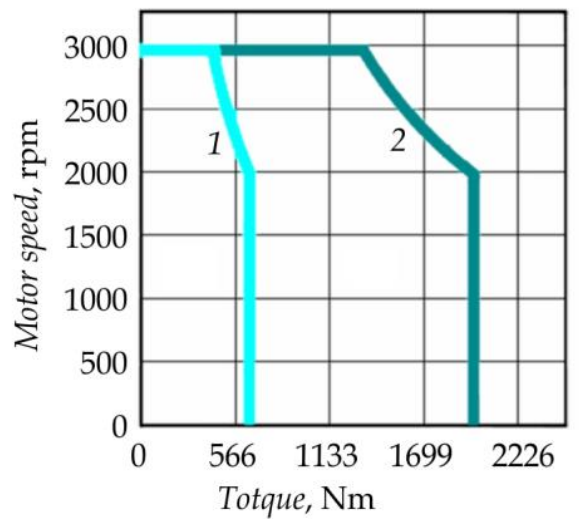

Figure 4. Load characteristics of EMG-10APA22: 1 - continuous working area; 2 - repeatedly working area

Table 3. Servomotor EMG-10APA22 measured dimensions

\begin{tabular}{lcc}
\hline \multicolumn{1}{c}{ Name } & Symbol & Value \\
\hline Stator and Rotor core length, & $L_{\delta}$ & 50 \\
mm & $D_{a}$ & 122 \\
Stator external diameter, mm & $D$ & 74 \\
Stator inner diameter, mm & $D_{r}$ & 72 \\
Rotor external diameter, $\mathrm{mm}$ & $D_{s}$ & 36 \\
Rotor inner diameter (for the & $W_{c}$ & 12 \\
shaft), mm & $N_{r}$ & 8 \\
Number of stator coils & $h_{m}$ & 7 \\
Number of permanent & $h_{p 1}$ & 3 \\
magnets &
\end{tabular}

- phase voltage

$U_{f}=\frac{U_{n}}{\sqrt{3}}$

- number of pole pairs

$p=\frac{60 \cdot f}{n}$;

- rated electromagnetic torque

$M_{n}=9.55 \frac{P_{n}}{n} ;$

- rated phase current

$I_{f}=\frac{P_{n}}{3 \cdot U_{f} \cdot P F \cdot \eta}$

where $P F$ is the power factor; $\eta$ is the efficiency;

- pole pitch

$\tau=\frac{\pi \cdot D}{2 \cdot p}$

- pole length (rotor package)

$L_{\delta}=\lambda \cdot \tau$,

where $\lambda$ is the relative ratio of length and pole pitch;

- air gap magnetic flux

$\Phi_{\delta}=\frac{B_{\delta} \cdot D \cdot L_{\delta}}{p} ;$ 
- phase EMF (preliminary)

$E_{f}=k_{e} \cdot U_{f}$,

where $k_{e}$ is the magnetic field form factor;

- number of turns per phase

$W_{1}=\frac{E_{f}}{4.44 \cdot f \cdot \Phi_{\delta}}$;

- number of turns in a coil

$W_{c}=\frac{W_{1} \cdot a}{p \cdot q}$,

where $a$ is the number of parallel branches; $q$ is the number of slots per pole and phase.

- cross-section of the winding wire

$q_{e f}=\frac{I_{f}}{J_{C u}}$,

where $J_{C u}$ is the winding current density;

- elementary conductor cross-section

$q_{e l}=\frac{q_{e f}}{n_{e l}}$,

where $n_{e l}$ is the number of parallel conductors;

- pole height:

$h_{p}=\frac{\left(D_{a}-D\right)}{2}-h_{p 1}$;

- number of conductors by pole height:

$N_{c}=\frac{h_{p}-h_{i n s}}{d_{e l}+\Delta_{i n s}}$,

where $h_{\text {ins }}$ is the insulation thickness at pole height; $\Delta_{\text {ins }}$ is the double-sided insulation thickness of winding wire;

In this case, the total thickness of the pole window will be:

$N_{c w}=\left(\frac{W_{c}}{N_{c}}+1\right) \cdot\left(d_{e l}+\Delta_{i n s}\right) ;$

- pole thickness

$b_{p}=\frac{0.5 \cdot \pi \cdot\left(D_{a}+D\right)}{N_{c}}-N_{c w}-\Delta_{c}$,

where $\Delta_{c}$ is the air gap between coils.

The calculation results of the servomotor, performed according to the presented formulas, are summarized in Table 4.

The received data is now enough to continue the calculation of the parameters and characteristics of the servomotor in RMxprt. In the presented paper, only key formulas are given.
Table 4. Servomotor parameters in addition to the rated data

\begin{tabular}{lc}
\hline \multicolumn{1}{c}{ Name } & Value \\
\hline Phase voltage, V & 127 \\
Number of poles & 8 \\
Poles pitch, mm & 29 \\
Air gap flux density, T & 0.75 \\
Air gap magnetic flux, Wb & 0.000694 \\
Number of slots per pole and phase & 1 \\
Number of parallel branches & 1 \\
Phase EMF, V & 123 \\
Number of turns in a coil & 75 \\
Number of elementary conductors & 2 \\
Conductor section, mm ${ }^{2}$ & 0.636 \\
Conductor diameter, mm & 0.9 \\
Double-sided conductor insulation & 0.065 \\
thickness, mm & 21 \\
Pole height, mm & 13 \\
Pole thickness, mm & \\
Insulation thickness along the pole & 5 \\
height, mm & 6 \\
Total thickness of the pole window, mm & 7 \\
Air gap between coils, mm & 0.61 \\
Power factor & 0.72 \\
Efficiency & 0.97 \\
Field shape factor & 1.7 \\
Ratio between stator diameter & \\
and pole pitch & \\
\hline
\end{tabular}

A detailed calculation was performed by the authors in a Python program [28, 29]. This approach of preliminary determination of parameters was given the author's name "Python Hot Start".

\section{PARAMETERS CALCULATION IN ANSYS RMXPRT}

ANSYS RMxprt it is needed to select the IPM Synchronous Motor (Incorporated Permanent Magnets) project type that matches the servomotor being tested (Fig. 5).

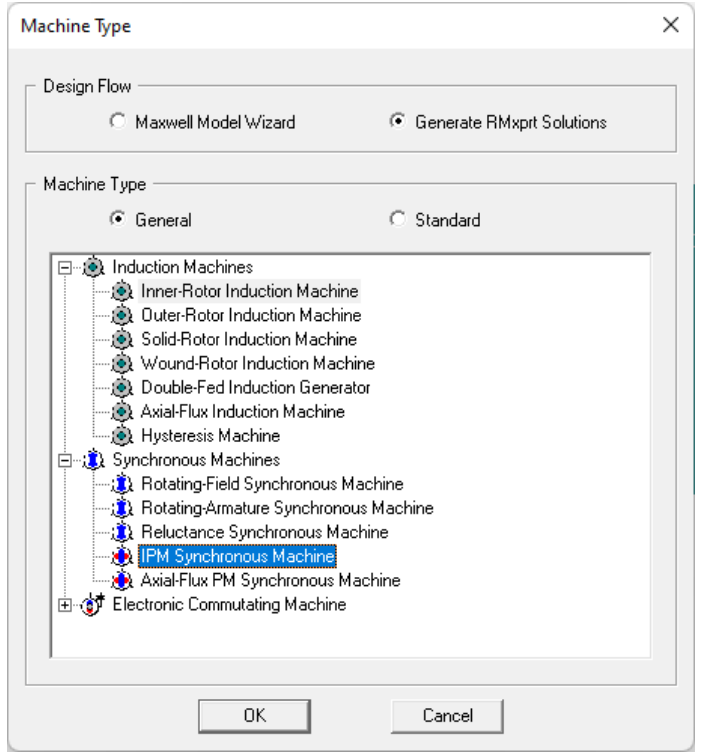

Figure 5. ANSYS RMxprt: project type selection 
Next, in the tree of the project manager, it is need sequentially fill in the tables of motor parameters and select the required materials (Fig. 6). Let's consider each of the steps of entering parameters [19].

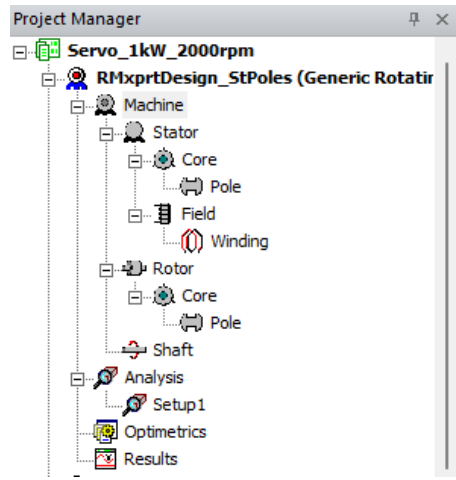

Figure 6. ANSYS RMxprt: machine characteristics tree

Machine. This section (Fig. 7) selects the stator type and rotor configuration. For the problem under consideration, a salient-pole stator with an internal rotor with built-in permanent magnets was chosen.

\begin{tabular}{l} 
Properties \\
\begin{tabular}{|l|l|l|l|}
\hline \multicolumn{1}{|c|}{ Name } & \multicolumn{1}{|c|}{ Value } & Unit & Evaluat \\
\hline Source Type & AC & & \\
\hline Structure & Inner Rotor & & \\
\hline Stator Type & SALNT_POLE & & \\
\hline Rotor Type & PM_INTERIOR & & \\
\hline & & \\
\hline
\end{tabular} \\
\hline
\end{tabular}

Figure 7. ANSYS RMxprt: global machine properties

Stator. Only the number of poles is specified on the stator properties tab (Fig. 8).

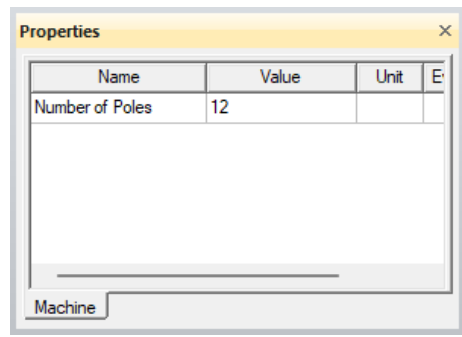

Figure 8. ANSYS RMxprt: stator properties

Stator Core. For the stator, the previously calculated geometric dimensions (Fig. 9), the steel filling factor are indicated, the steel material is selected from the program database (it is possible to create user material by setting the magnetization curve) and the pole type is selected (Fig. 10).

Stator Core Pole. In this section, the dimensions of the pole are set. The pole suggested by the program (Fig. 10) does not correspond to the real pole of the tested servomotor, however, by specifying the dimensions of the pole, shoe and the length of the arcs, an acceptable match can be achieved (Fig. 11, 12).

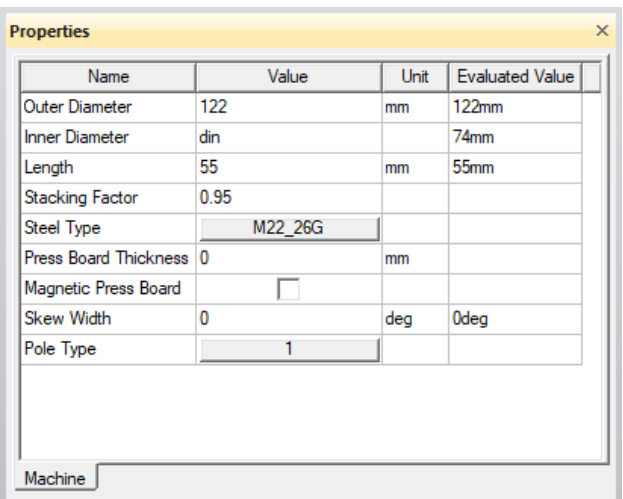

Figure 9. ANSYS RMxprt: stator core parameters

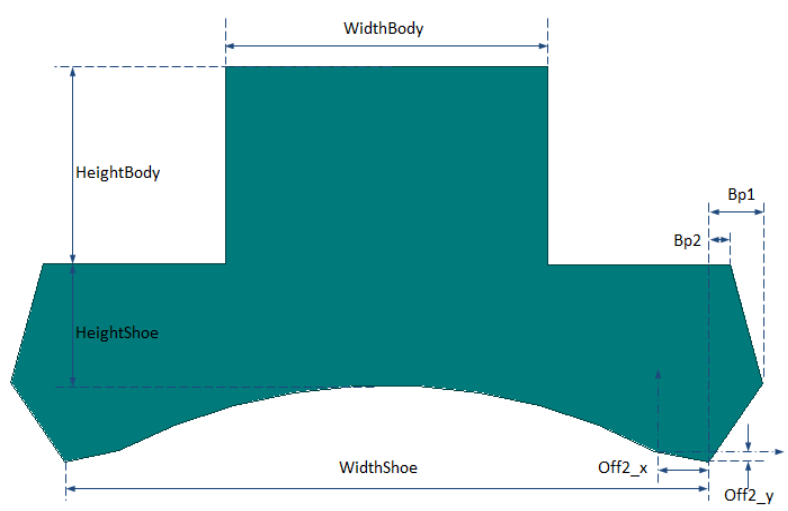

Figure 10. ANSYS RMxprt: sketch of poles

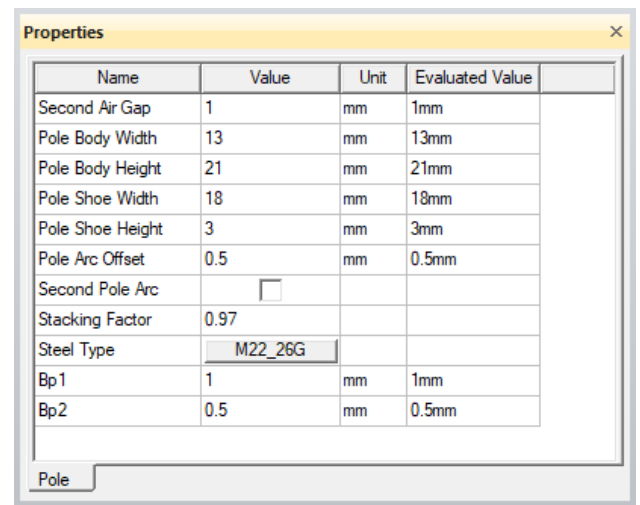

Figure 11. ANSYS RMxprt: inductor pole parameters

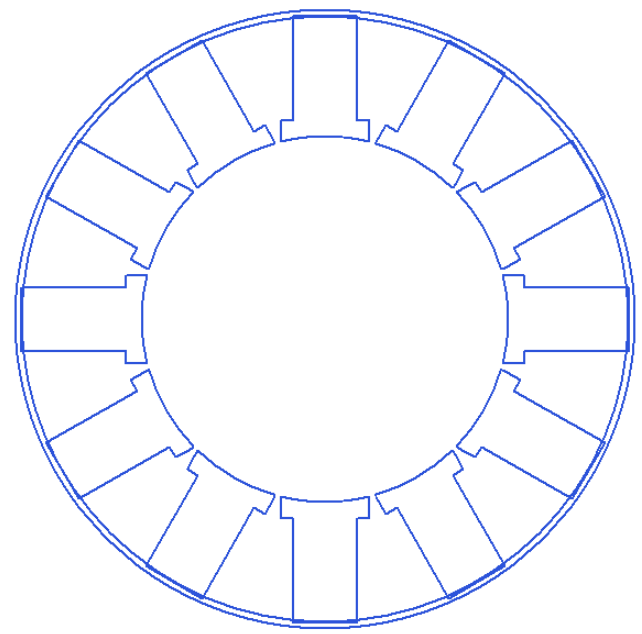

Figure 12. ANSYS RMxprt: sketch of a stator with poles 
Stator Field. The coil parameters window (Fig. 13) shows the pole insulation, power supply efficiency and field current.

Properties
\begin{tabular}{|l|l|l|l|}
\hline \multicolumn{1}{|c|}{ Name } & \multicolumn{1}{|c|}{ Value } & \multicolumn{1}{c|}{ Unit } & Evaluated Value \\
\hline Shoe Insulation & 0.5 & $\mathrm{~mm}$ & \\
\hline Pole Insulation & 0.5 & $\mathrm{~mm}$ & \\
\hline Winding Clearance & 1 & $\mathrm{~mm}$ & \\
\hline Exciter Efficiency & 0.95 & & \\
\hline Exciting Current & 6 & $\mathrm{~A}$ & $6 \mathrm{~A}$ \\
\hline & & & \\
\hline & & & \\
\hline Machine &
\end{tabular}

Figure 13. ANSYS RMxprt: excitation system characteristics

Stator Field Winding. For the coil winding, its type is selected (the program includes coils with rectangular conductors wound flat and on an edge), the number of conductors, their dimensions, as well as the material of the winding wire (Fig. 14).

\begin{tabular}{|c|c|c|c|}
\hline Properties & & & \\
\hline Name & Value & Unit & Evaluated Value \\
\hline Winding Type & RoundWire & & \\
\hline Parallel Branches & 1 & & \\
\hline Conductors per Pole & 75 & & 75 \\
\hline Number Of Strands & 2 & & \\
\hline Wire Wrap & 0.065 & $\mathrm{~mm}$ & \\
\hline Wire Size & Diameter: $0.9 \mathrm{~mm}$ & & \\
\hline Conductor Type & copper_ $75 \mathrm{C}$ & & \\
\hline Axial Clearance & 0 & $\mathrm{~mm}$ & $\mathrm{Omm}$ \\
\hline Winding Fillet & 0 & $\mathrm{~mm}$ & Omm \\
\hline Limited Cross Width & 0 & $\mathrm{~mm}$ & Omm \\
\hline Limited Cross Height & 0 & $\mathrm{~mm}$ & $0 \mathrm{~mm}$ \\
\hline
\end{tabular}

Figure 14. ANSYS RMxprt: winding parameters of inductors

Rotor. For the rotor, as before for the stator, the number of poles is indicated (Fig. 15).

\begin{tabular}{l} 
Properties \\
\begin{tabular}{|l|l|c|c|c|}
\hline \multicolumn{1}{|c|}{ Name } & \multicolumn{1}{|c|}{$\times$} \\
\hline Number of Poles & 8 & Unit & Evaluated Value \\
\hline
\end{tabular} \\
\hline
\end{tabular}

Figure 15. ANSYS RMxprt: rotor properties

Rotor Core. In the parameters of the rotor core, the outer diameter was given in the form of a formula (Fig. 16), relating its value to the air gap and the inner diameter of the stator. The rotor length, core material and pole type are also indicated. Among the types of poles available in the program, the one corresponding to the prototype was chosen (Fig. 17).

Rotor Core Pole. In this tab one can set the dimensions and select the material of the permanent magnets. (Fig. 18).

After the performed operations, a complete sketch of the servo motor becomes available (Fig. 19).

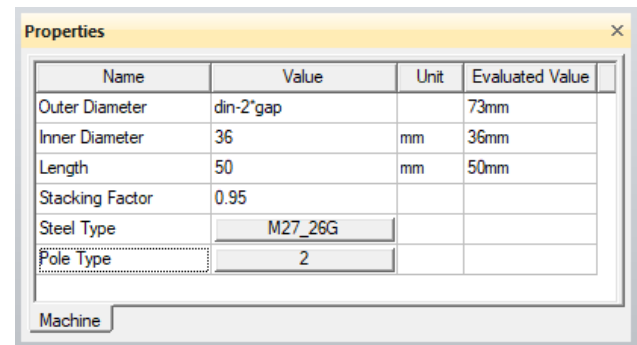

Figure 16. ANSYS RMxprt: rotor core parameters

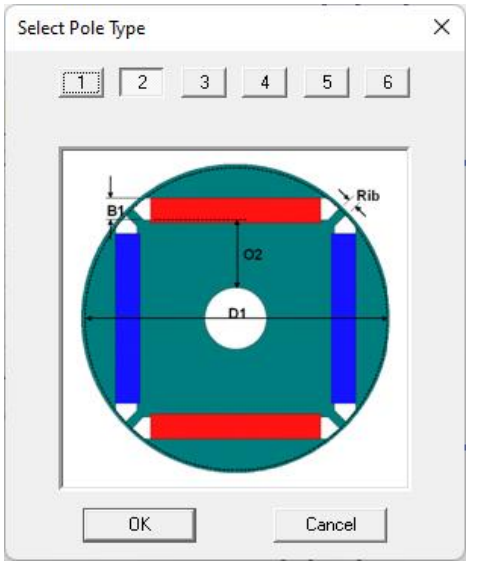

Figure 17. ANSYS RMxprt: selection of the permanent magnets type

\begin{tabular}{|c|c|c|c|}
\hline \multicolumn{4}{|l|}{ Properties } \\
\hline Name & Value & Unit & Evaluated Value \\
\hline D1 & din-2"gap-2"bridge & & $71 \mathrm{~mm}$ \\
\hline 02 & 14 & $\mathrm{~mm}$ & $14 \mathrm{~mm}$ \\
\hline B1 & 2.5 & $\mathrm{~mm}$ & $2.5 \mathrm{~mm}$ \\
\hline Rib & 1 & $\mathrm{~mm}$ & $1 \mathrm{~mm}$ \\
\hline Layers & 1 & & 1 \\
\hline Layer Pitch & 0 & $\mathrm{~mm}$ & $\mathrm{Omm}$ \\
\hline Magnet Thickness & 3 & $\mathrm{~mm}$ & $3 \mathrm{~mm}$ \\
\hline Magnet Width & 15 & $\mathrm{~mm}$ & $15 \mathrm{~mm}$ \\
\hline Magnet Type & $\mathrm{NdFe} 30$ & & \\
\hline
\end{tabular}

Figure 18. ANSYS RMxprt: permanent magnets dimensions

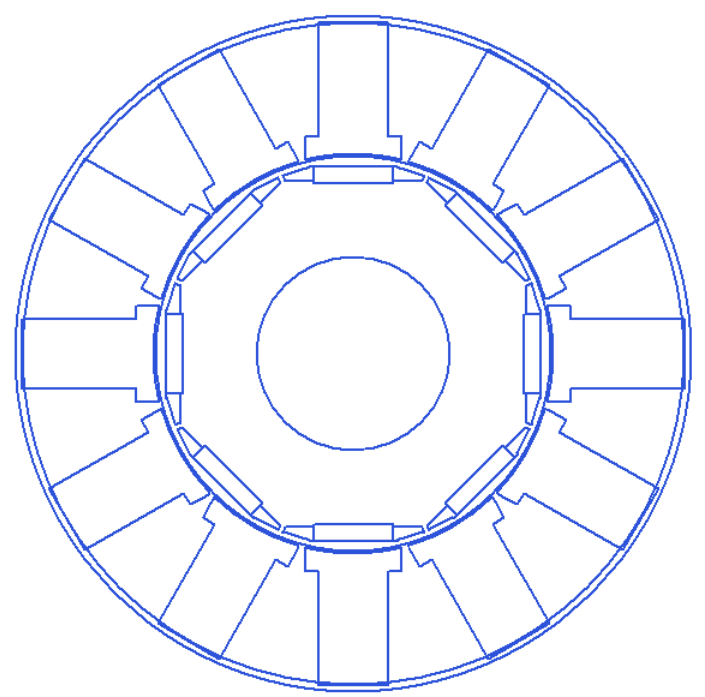

Figure 19. ANSYS RMxprt: servo motor sketch 
Shaft. For the shaft, the presence of a magnetic material is selected in the properties, ventilation and friction losses in the bearings are set at the nominal speed (Fig. 20).

\begin{tabular}{l} 
Properties \\
\begin{tabular}{|l|l|l|l|l|}
\hline \multicolumn{1}{|c|}{ Name } & \multicolumn{2}{|c|}{ Value } & Unit & Evaluated Value \\
\hline Magnetic Shaft & \multicolumn{2}{|c|}{ 『 } & & \\
\hline Frictional Loss & 5 & & $W$ & $5 W$ \\
\hline Windage Loss or Power & 5 & W & $5 W$ \\
\hline Reference Speed & 2000 & pm & \\
\hline & & & \\
\hline
\end{tabular} \\
Shaft \\
\hline
\end{tabular}

Figure 20. ANSYS RMxprt: shaft parameters

Analysis. The analysis tab initially does not contain attached properties, in order to create them, after clicking the right mouse button, the context menu item "Add Solution Setup" is selected.

Analysis Setup. This group of properties is final and consists of two tabs. The first (Fig. 21a) selects the operating mode and nominal motor data, and the second (Fig. 21b) selects the operating frequency and power factor.

\begin{tabular}{|c|c|c|c|}
\hline \multicolumn{4}{|l|}{ Properties } \\
\hline Name & Value & Unit & Evaluated Value \\
\hline Name & Setup1 & & \\
\hline Enabled & $\sqrt{v}$ & & \\
\hline Operation Type & Motor & & \\
\hline Load Type & Const Power & & \\
\hline Rated Output Power & 1000 & W & $1000 \mathrm{~W}$ \\
\hline Rated Voltage & 200 & V & $200 \mathrm{~V}$ \\
\hline Rated Speed & 2000 & $\mathrm{pmm}$ & $2000 \mathrm{~mm}$ \\
\hline Operating Temperature & 75 & cel & $75 \mathrm{cel}$ \\
\hline
\end{tabular}

(a)

Properties
\begin{tabular}{|l|c|c|c|}
\hline \multicolumn{1}{|c|}{ Name } & \multicolumn{1}{|c|}{ Value } & Unit & Evaluated Value \\
\hline Rated Power Factor & 0.65 & & \\
\hline Capacitive Power Factor & \multicolumn{1}{|c|}{$\Gamma$} & & \\
\hline Frequency & 133 & $\mathrm{~Hz}$ & $133 \mathrm{~Hz}$ \\
\hline & & & \\
\hline General \\
\hline
\end{tabular}

(b)

Figure 21. ANSYS RMxprt: solver properties: (a) solver properties (part 1); (b) solver properties (part 2)

The results of the analysis are shown below and show satisfactory convergence with the servo motor nameplate data. In particular, the main key parameters coincided (torque and phase current), and the rest are within acceptable limits in terms of the requirements for electric machines in general (magnetic flux density, current density, losses, efficiency).

Fig. 22-26 shows the servomotor characteristics obtained in RMxprt.

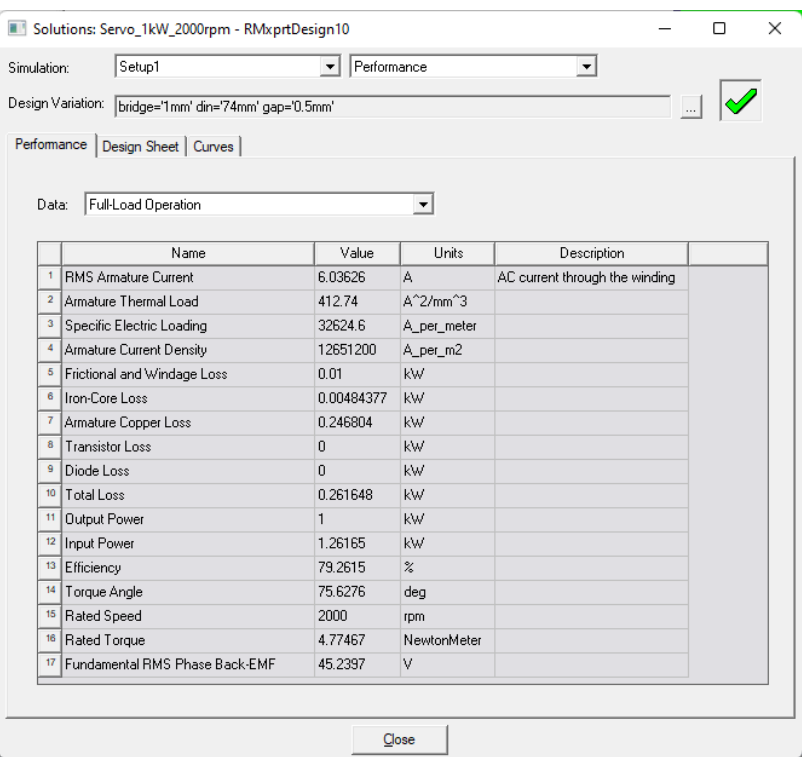

Figure 22. ANSYS RMxprt: Servomotor calculation report (data under load)

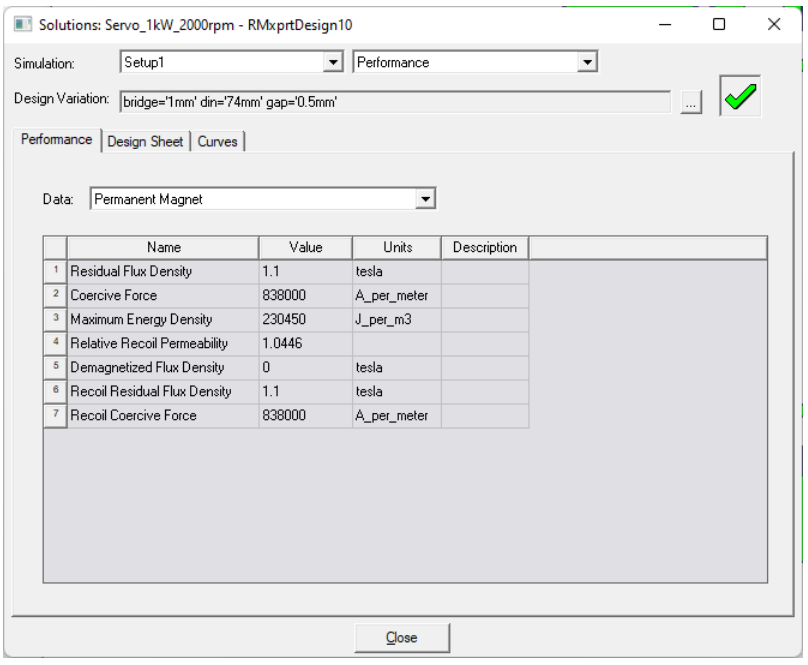

Figure 23. ANSYS RMxprt: permanent magnet solver report

\section{TRANSIENT MODELING IN ANSYS SIMPLORER}

The ANSYS Simplorer software package allows to simulate the transient characteristics of electrical machines not only on the basis of mathematical models set by differential equations or built-in machine models, but also in coupling with previous projects in RMxprt or ANSYS Maxwell 2D/3D [19]. That approach in ANSYS called Twin Builder. To solve this problem, a Twin Builder component was inserted into the Simplorer worksheet for coupling simulation analysis of the servomotor dynamic modes based on a machine object from the RMxprt project.

In this paper, the first phase of the problem is solved - to link the RMxprt project with the Simplorer power supply and obtain the output characteristics. 


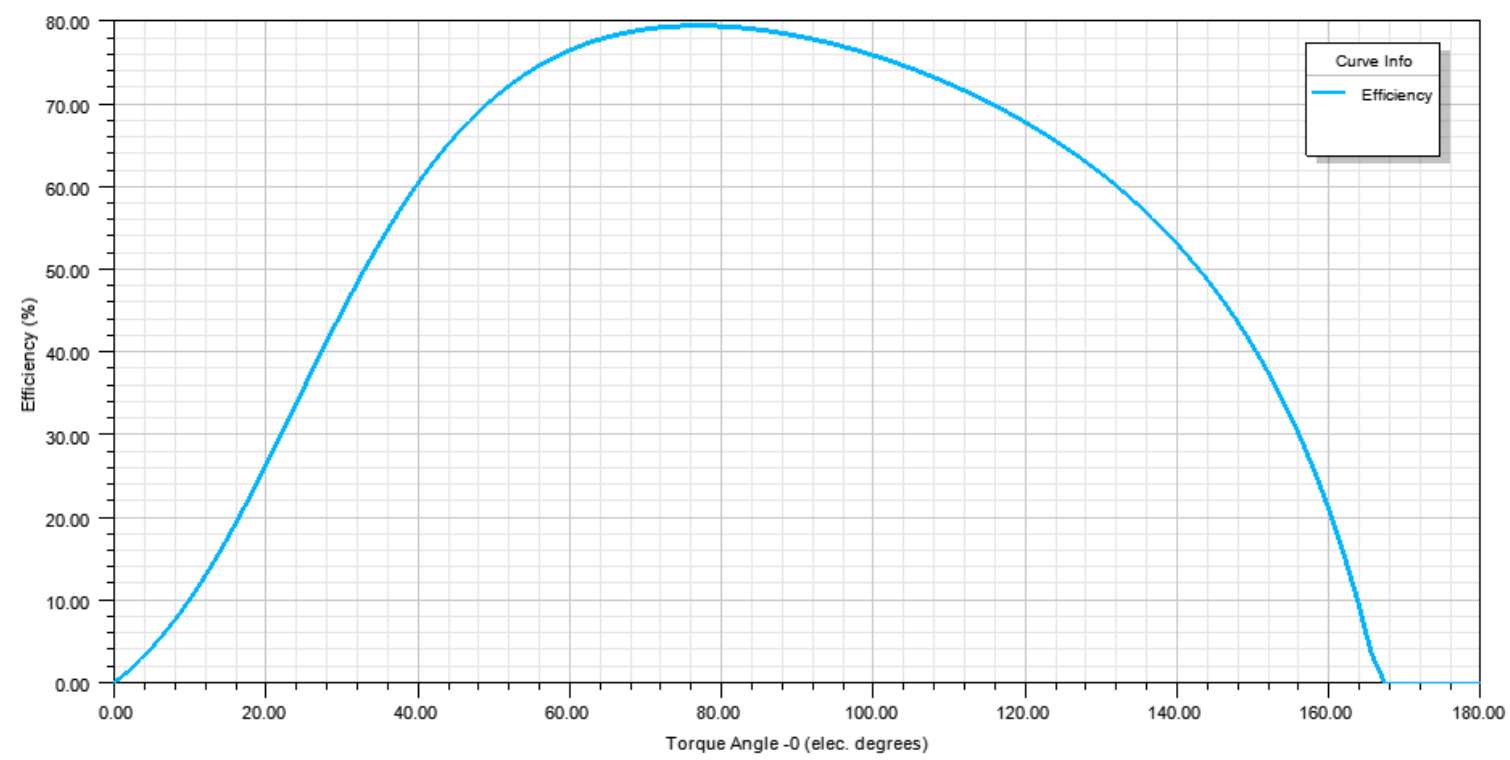

Figure 24. Efficiency vs Torque Angle

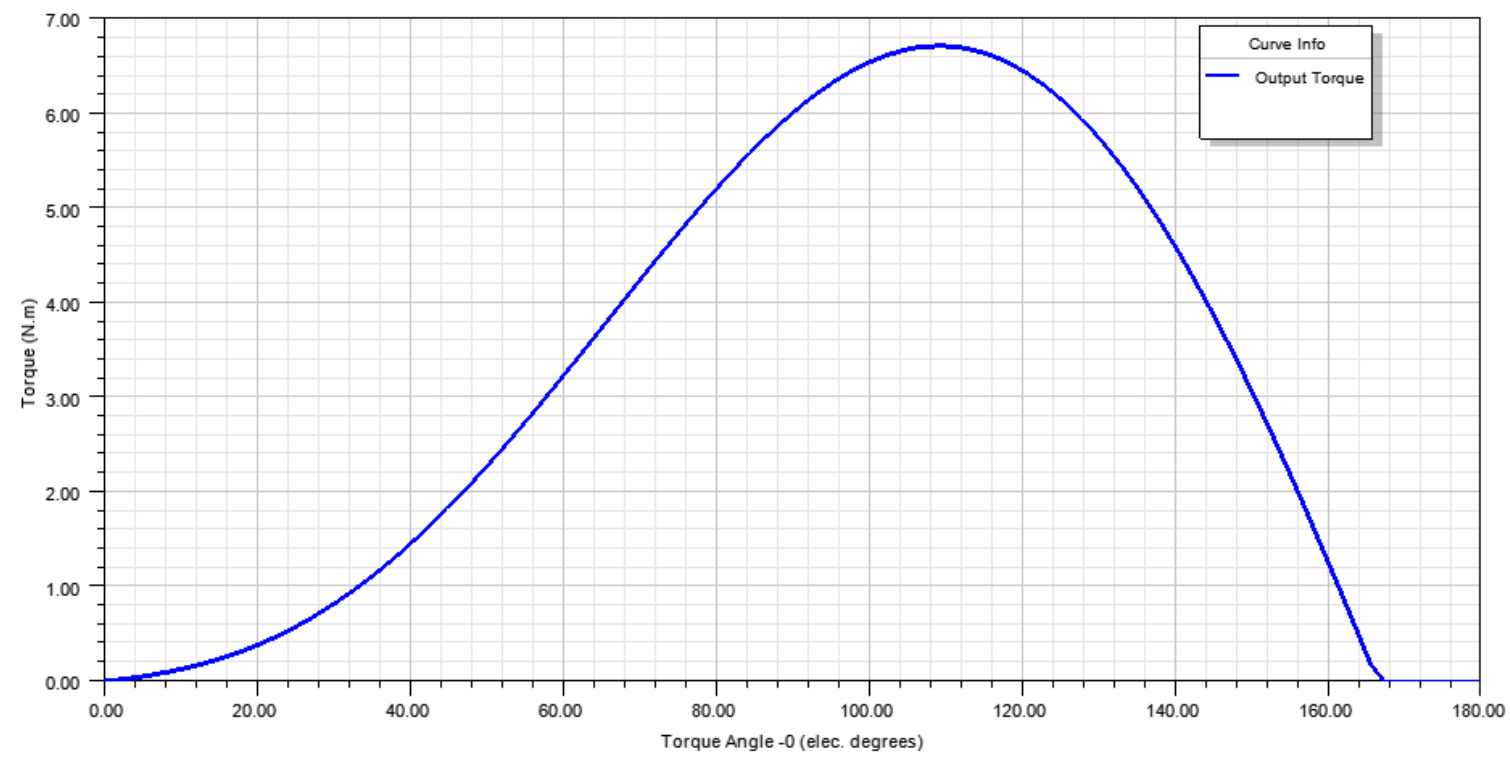

Figure 25. Output Torque vs Torque Angle

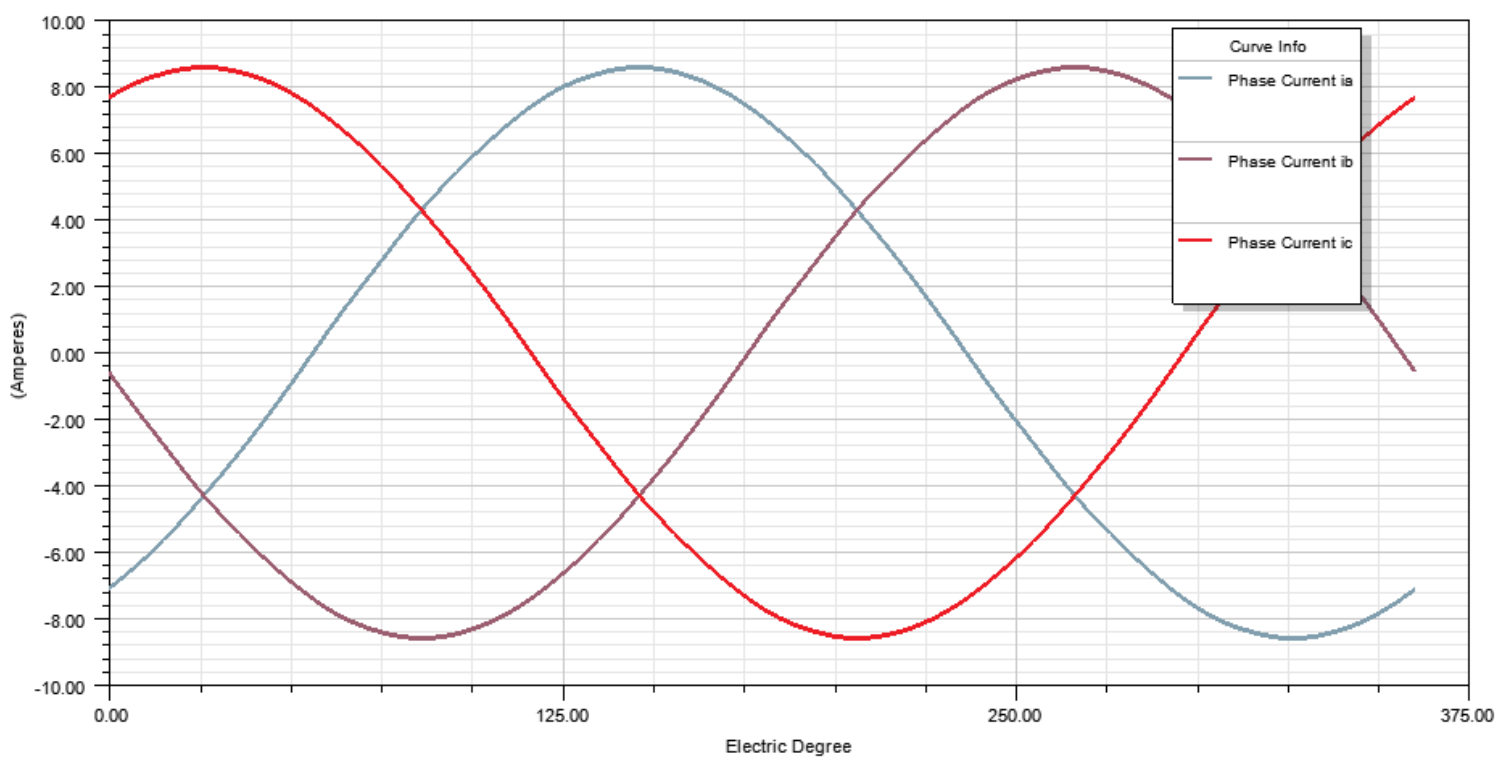

Figure 26. Winding Currents under Load 


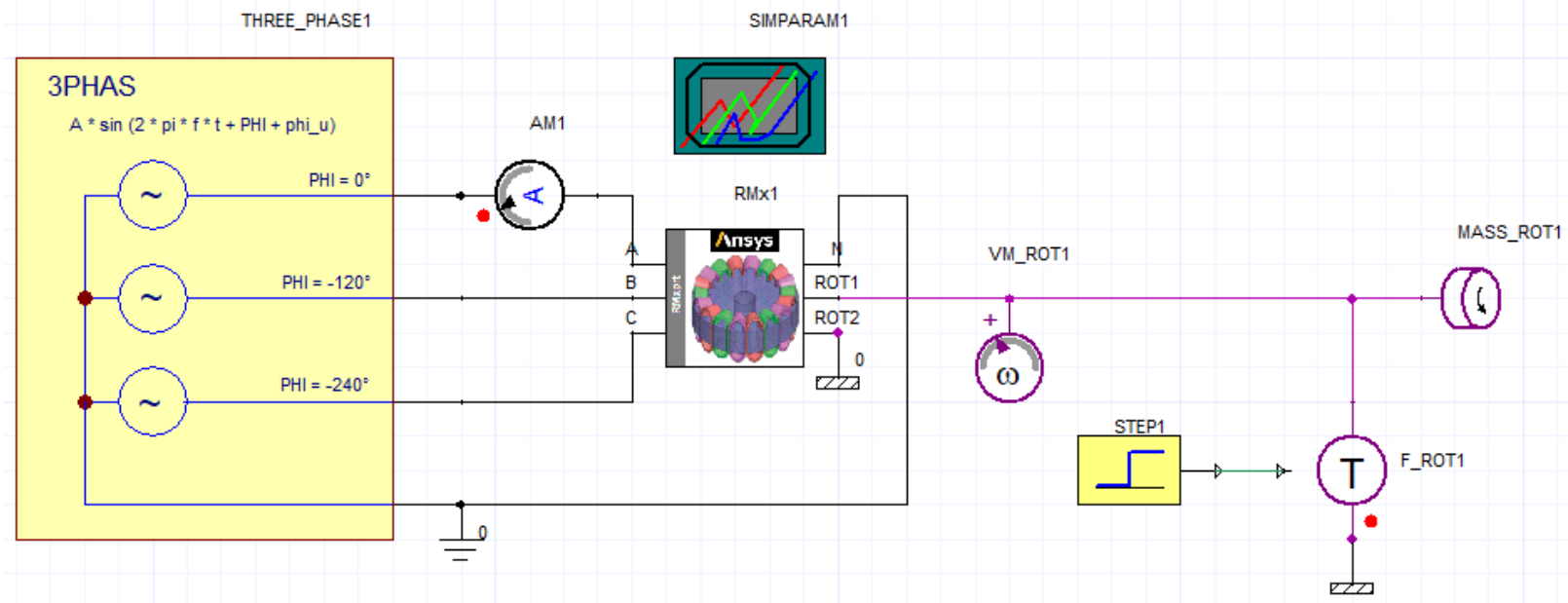

Figure 27. ANSYS Simplorer: simulated servomotor with a stable power supply

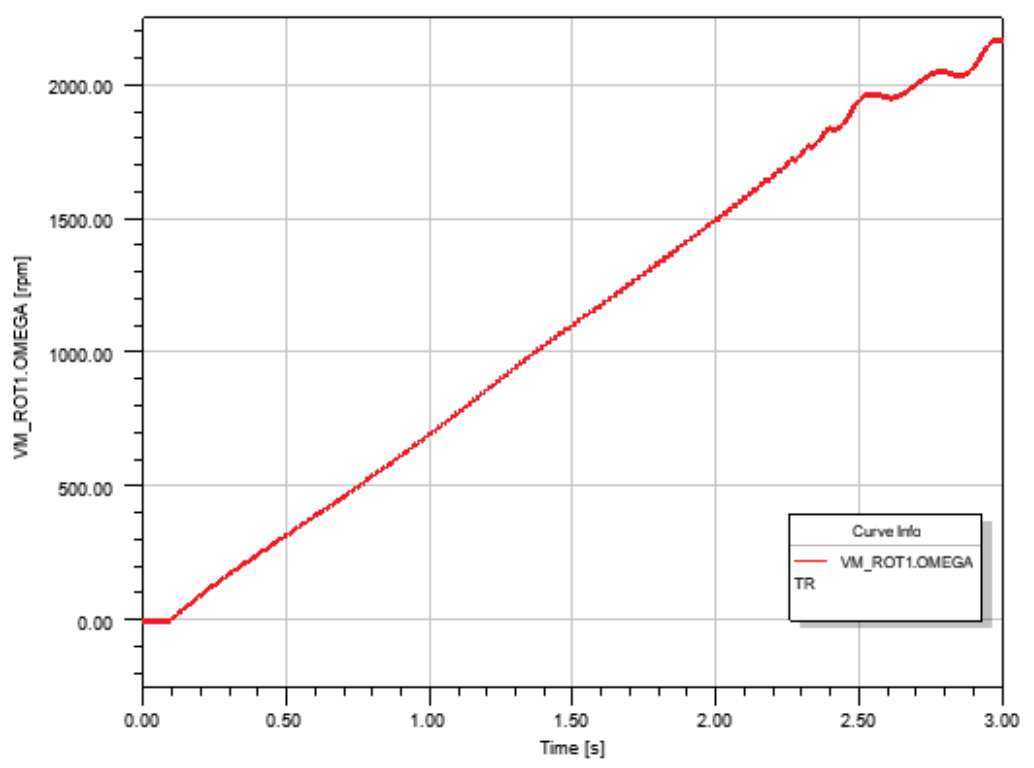

Figure 28. Rotational Speed vs Time

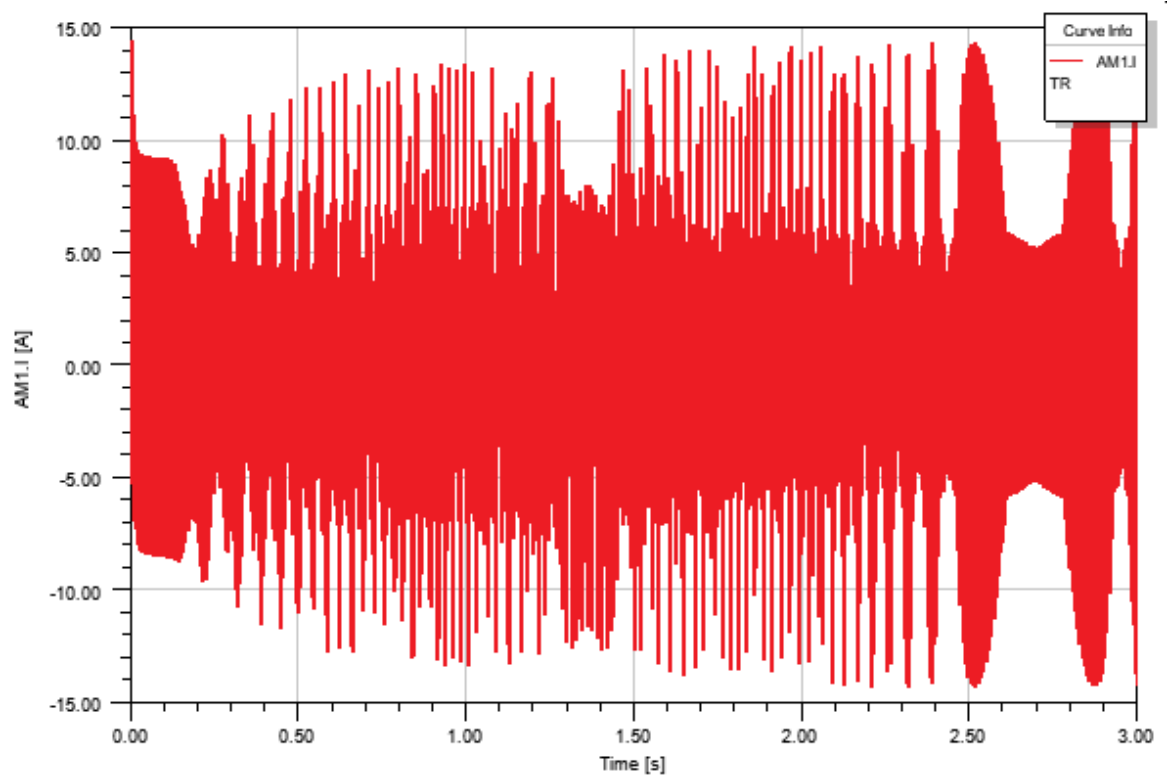

Figure 29. Phase Current vs Time 
In future works, more complex circuits for simulating transient processes in a servo motor, taking into account power from a frequency converter, using a speed sensor and variable loads, will be shown.

Fig. 27 shows a simulation model, which shows a three-phase power supply 3PHAS, a servo motor object from RMxprt $R M x 1$, an amperemeter $A M 1$, a tachometer VM_ROT1, a rotor inertia source MASS_ROT1, a step load generator STEP1, and a torque sensor F_ROT1.

In the settings of the three-phase power supply and the element characterizing the inertia value, the data from the project were passed. The rated load in the STEP1 block was applied at the time $0.1 \mathrm{~s}$. The simulated characteristics are shown in Fig. 28 and Fig. 29.

The values of the rotor speed and the value of the effective value of the stator winding phase current, obtained during the stabilization of the transient process correspond to the values obtained both as a result of preliminary design and the rated data of the servomotor.

\section{CONCLUSIONS}

The use of the ANSYS software package for the analysis of parameters and characteristics of electrical machines in general and the servomotor considered in this article in particular is justified in cases where geometric and winding data are known. Therefore, in this article, the problem of preliminary design of a servomotor was solved for subsequent calculations in ANSYS.

The software module RMxprt, included in ANSYS Electromagnetics software, allows, after the transformations shown in this article, to obtain, based on a standard design of a synchronous machine with built-in permanent magnets, a design of a servomotor with salient stator poles and a concentrated winding. The criterion for the correctness of the calculations is the maximum approximation of the key characteristics to the rated data of the tested motor. Thus, the target values of the phase current of $6 \mathrm{~A}$, the rotation speed of $2000 \mathrm{rpm}$, the torque on the shaft of $4.78 \mathrm{Nm}$ and other parameters were achieved.

The Simplorer software module, included in ANSYS Electromagnetics, made it possible to simulate the dynamic modes of a servomotor without using the standard blocks of electrical machines and mathematical models. Instead, an alternative way of embedding a servomotor object, calculated in RMxprt, into the Simplorer simulation field was shown, and then obtaining the transient characteristics of the machine.

In this paper, we examined the simulation of the dynamic modes of a servo motor in ANSYS Simplorer using a stable three-phase power supply (ampli- tude $127 \mathrm{~V}$, frequency $133 \mathrm{~Hz}$ ), considering the rated load connection during the acceleration phase. In future work, it is planned to perform a detailed simulation of a servomotor using an embedded servomotor object from RMxprt and using power from a frequency converter together with implementing speed feedback.

\section{DISCLOSURE STATEMENT}

No potential conflict of interest was reported by the author(s).

\section{REFERENCES}

1. Nicolescu, A., Avram, C., \& Ivan, M. (2014). Optimal servomotor selection algorithm for industrial robots and machine tools NC axis. Proceedings in Manufacturing Systems, 9(2), 105-114. http://icmas.eu/Journal_archive_ files/Vol_9-Issue2_2014_PDF/105-114_Nicolescu.pdf

2. Yamazaki, T. (2017). Experimental study on dynamic behavior of high precision servo motor for machine tools. Applied Mechanics and Materials, 863, 224-228. https: //doi.org/10.4028/www.scientific.net/AMM.863.224

3. Kombarov, V., Sorokin, V., Tsegelnyk, Y., Plankovskyy, S., Aksonov, Y., \& Fojtů, O. (2021). Numerical control of machining parts from aluminum alloys with sticking minimization. International Journal of Mechatronics and Applied Mechanics, 1(9), 209-216. https://doi.org/10. 17683/ijomam/issue9.30

4. Abdul Ali, A.W., Abdul Razak, F.A., \& Hayima, N. (2020). A review on the AC servo motor control systems. ELEKTRIKA - Journal of Electrical Engineering, 19(2), 22-39. https://doi.org/10.11113/elektrika.v19n2.214

5. Hossain, A., \& Rasheduzzaman, M. (2011). Integrating servomotor concepts into mechatronics engineering technology curriculum emphasizing high speed packaging machinery. In 2011 ASEE Annual Conference \& Exposition (p. 22.915). ASEE. https://doi.org/10.18260/1-2-18244

6. Voss, W. (2007). A Comprehensible Guide to Servo Motor Sizing. Copperhill Media.

7. Vagati, A., Fratta, A., Franceschini, G., \& Rosso, P. (1996). AC motors for high-performance drives: a designbased comparison. IEEE Transactions on Industry Applications, 32(5), 1211-1219. https:// doi.org/10.1109/28.536885

8. Huang, C., Lei, F., Han, X., \& Zhang, Z. (2019). Determination of modeling parameters for a brushless DC motor that satisfies the power performance of an electric vehicle. Measurement and Control, 52(7-8), 765-774. https://doi.org/10.1177/0020294019842607

9. ESTUN. (2021). AC Servo Motor. http:// estun.com. ua/pdf/ac_servo_motor.pdf

10. Shinde, P.S., Thosar, A.G., \& Ratnani, P.L. (2015). Design of permanent magnet synchronous motor. International Journal of Scientific E Engineering Research, 6(1), 107110. https://ijser.org/researchpaper/design-of-permanen t-magnet-synchronous-motor.pdf 
11. Shen, Q., Sun, N., Zhao, G., Han, X., \& Tang, R. (2010). Design of a permanent magnet synchronous motor and performance analysis for subway. In 2010 Asia-Pacific Power and Energy Engineering Conference (pp. 1-4). IEEE. https://doi.org/10.1109/APPEEC.2010.5449212

12. Isfahani, A.H., \& Sadeghi, S. (2008). Design of a permanent magnet synchronous machine for the hybrid electric vehicle. World Academy of Science, Engineering and Technology, 45, 566-570. https://doi.org/10.5281/zenodo. 1332212

13. Panigrahi, B.P., Patra, K.C., Subbarao, V., \& Prasad, D. (1999). Design of a permanent magnet synchronous motor. Electric Machines \& Power Systems, 27(7), 771-779. https://doi.org/10.1080/073135699269000

14. Akar, M., \& Temiz, I. (2007). Motion controller design for the speed control of DC servo motor. International Journal of Applied Mathematics and Informatics, 4(1), 131-137. http://www.wseas.us/journals/ami/ami-19.pdf

15. Zhang, Y., Yang, Z., Yu, M., Lu, K., Ye, Y., \& Liu, X. (2011). Analysis and design of double-sided air core linear servo motor with trapezoidal permanent magnets. IEEE Transactions on Magnetics, 47(10), 3236-3239. https://doi. org/10.1109/TMAG.2011.2156398

16. Hanselman, D.C. (2003). Brushless Permanent Magnet Motor Design. The Writers' Collective.

17. Chenwei, Y., Fei, D., Yi, A., \& Fengqing, Z. (2021). Design and analysis of permanent magnet synchronous servo motor with low rotational inertia and high torque density. Journal of Physics: Conference Series, 1965(1), 012010. https://doi.org/10.1088/1742-6596/1965/1/012010

18. Deeb, R., Janda, M., \& Makki, Z. (2012). Comparison of 2D and 3D FEM analysis of the magnetic field in a PM servo motor. Electrical Engineering, 72, 297-309. https://yadda.icm.edu.pl/baztech/element/bwmeta1.ele ment.baztech-2e33696a-32cc-4941-8c0a-4369c102e081/c/d eeb_ramia_comparison_72_2012.pdf

19. Pliugin, V., Petrenko, O., Grinina, V., Grinin, O., \& Yehorov, A. (2017). Imitation model of a high-speed induction motor with frequency control. Electrical Engineering $\mathcal{E}$ Electromechanics, (6), 14-20. https://doi.org/10. 20998/2074-272X.2017.6.02

20. Gope, D., \& Goel, S.K. (2021). Design optimization of permanent magnet synchronous motor using Taguchi method and experimental validation. International Journal of Emerging Electric Power Systems, 22(1), 9-20. https:/ / doi. org/10.1515/ijeeps-2020-0169
21. Luu, P.T., Lee, J.Y., Lee, J.H., \& Woo, B.C. (2019). Design and analysis of a permanent magnet synchronous motor considering axial asymmetric position of rotor to stator. Energies, 12(24), 4816. https://doi.org/10.3390/ en12244816

22. Ding, W.T., An, L.X., Wang, C.M., Huang, Y.P., Long, T., \& Jiang, M.L. (2015). Multidisciplinary integrated simulation and design optimization framework for electromechanical servo system. Applied Mechanics and Materials, 704, 263-269. https://doi.org/10.4028/www. scientific.net/AMM.704.263

23. Lu, H., \& Guru, A.K. (2013). Modeling conducted emissions in servo drives. In 2013 IEEE 8th Conference on Industrial Electronics and Applications (ICIEA) (pp. 9991004). IEEE. https:// doi.org/10.1109/ICIEA.2013.6566513

24. Lei, H., Chen, Y., Chen, D., Li, Z., \& Zhu, H. (2021). Design and analysis of permanent magnet AC servo motor based on ANSYS. Journal of Physics: Conference Series, 1754(1), 012151. https:// doi.org/10.1088/1742-6596/1754 $/ 1 / 012151$

25. Krishnan, R. (1987). Selection criteria for servo motor drives. IEEE Transactions on Industry Applications, IA23(2), 270-275. https:// doi.org/10.1109/TIA.1987.4504902

26. Qiu, H., Zhang, Y., Yang, C., \& Yi, R. (2020). Analysis of permanent magnet servo motor performance with different semi-ferromagnetic sleeve materials. Transactions of the Canadian Society for Mechanical Engineering, 45(1), 1121. https:// doi.org/10.1139/tcsme-2019-0201

27. Shavkun, V. (2020). Methodology for the assessment of the operation reliability of pulling electric machines of city electric transport. Lighting Engineering $\mathcal{E}$ Power Engineering, 58(2), 58-64. https://doi.org/10.33042 /2079-424X-2020-2-58-13-19 (in Ukrainian)

28. Pliuhin, V., Korobka, V., Karyuk, A., Pan, M., \& Sukhonos, M. (2019). Using Azure Machine Learning Studio with Python scripts for induction motors optimization web-deploy project. In 2019 IEEE International Scientific-Practical Conference Problems of Infocommunications, Science and Technology (PIC SET) (pp. 631-634). IEEE. https://doi.org/10.1109/PICST47496.2019.9061447

29. Pliuhin, V., Sukhonos, M., \& Bileckiy, I. (2020). Object oriented mathematical modeling of electrical machines. In 2020 IEEE 4th International Conference on Intelligent Energy and Power Systems (IEPS) (pp. 267-272). IEEE. https://doi.org/10.1109/IEPS51250.2020.9263158

\title{
Проектування та моделювання сервоприводного двигуна за допомогою використання ANSYS Electromagnetics
}

\author{
Владислав Плюгін, Олександр Аксьонов, Свген Цегельник, Сергій Планковський, \\ Володимир Комбаров, Лідія Піддубна
}

Анотація. Стаття присвячена визначенню вихідних параметрів серводвигуна, який відноситься до синхронних
машин з постійними магнітами, з метою подальшого визначення характеристик динамічних режимів в програ-
мному пакеті ANSYS Electromagnetics. Програма RMхрrt, яка входить до ANSYS Electromagnetics, дозволяє визна-
чити параметри обмоток, втрати, робочі характеристики двигуна, але вимагає заповнення формуляру 3 повним
набором геометричних розмірів та обмоткових даних. Звичайно, такі дані відсутні у паспорті двигуна, тому пе-
рша задача, яка вирішена у статті - це визначення всіх необхідних і достатніх параметрів для виконання розра-
хунку в RMхрrt. Результати розрахунків були порівняні із вимірюваннями за допомогою експериментального
зразку серводвигуна моделі EMG-10APA22. У статті показано, як виконати експорт об'єкту серводвигуна 3
RMхрrt у робочій простір програми Simplorer, яка також входить до пакету ANSYS Electromagnetics. За результа- 
тами моделювання в ANSYS Simplorer отримано характеристики перехідних режимів серводвигуна при живленні від стабільного трифазного джерела. Показано перспективи подальших досліджень, пов' язаних 3 удосконаленням імітаційної моделі в ANSYS Simplorer.

Ключові слова: сервоприводний двигун, вбудовані магніти, ANSYS Simplorer, Twin Builder, параметри двигуна.

\section{NOTES ON CONTRIBUTORS}

\section{Vladyslav Pliuhin}

vladyslav.pliuhin@kname.edu.ua

\section{Oleksandr Aksonov}

oleksandr.aksonov@kname.edu.ua

\section{Yevgen Tsegelnyk}

y.tsegelnyk@kname.edu.ua

\section{Sergiy Plankovskyy}

sergiy.plankovskyy@kname.edu.ua

\section{Volodymyr Kombarov}

volodymyr.kombarov@kname.edu.ua

\section{Lidiia Piddubna}

lidiya.piddubna@kname.edu.ua
D.Sc., Professor

Department of Urban Power Supply Systems and Power Consumption

O. M. Beketov National University of Urban Economy in Kharkiv, Kharkiv, Ukraine

(iD) https://orcid.org/0000-0003-4056-9771

p https://publons.com/researcher/F-4627-2018/

SC https:// scopus.com/authid/ detail.uri?authorId $=57204286328$

Postgraduate student

Department of Urban Power Supply Systems and Power Consumption

O. M. Beketov National University of Urban Economy in Kharkiv, Kharkiv, Ukraine

(iD) https:/ / orcid.org/0000-0002-1870-524X

Ph.D., Associate Professor

Department of Automation and Computer-Integrated Technologies

O. M. Beketov National University of Urban Economy in Kharkiv, Kharkiv, Ukraine

(iD) https:// orcid.org/0000-0003-1261-9890

p https://publons.com/researcher/J-1570-2015/

SC https:// scopus.com/authid/ detail.uri?authorId $=57192961558$

D.Sc., Professor

Department of Automation and Computer-Integrated Technologies

O. M. Beketov National University of Urban Economy in Kharkiv, Kharkiv, Ukraine

(iD) https://orcid.org/0000-0003-2908-903X

p https://publons.com/researcher/H-6120-2015/

SC https://www.scopus.com/authid/detail.uri?authorId=24473286300

Ph.D., Associate Professor

Department of Automation and Computer-Integrated Technologies

O. M. Beketov National University of Urban Economy in Kharkiv, Kharkiv, Ukraine

(iD) https:// orcid.org/0000-0002-6158-0374

SC https://www.scopus.com/authid/ detail.uri?authorId=57211793853

Ph.D., Associate Professor

Department of Automation and Computer-Integrated Technologies

O. M. Beketov National University of Urban Economy in Kharkiv, Kharkiv, Ukraine

(iD) https://orcid.org/0000-0002-4225-1612

p https://publons.com/researcher/L-7161-2016/

https://www.scopus.com/authid/detail.uri?authorId=57331472000 